\title{
Chapter 11 \\ Mediation and Conciliation in Collective \\ Labor Conflicts in Portugal
}

\author{
Andreia Pinheiro, Ana Margarida Passos and Alan Stoleroff
}

\section{The Case}

In 2016, a trade union made a request to DGERT for conciliation in a dispute. The reported conflict involved a union and an employers' association, and was based on a review of a collective agreement that had not been revised since 2008. The request was motivated by the fact that a set of practical changes had already been implemented but had not been previously formalized within the collective agreement.

When the parties started to negotiate, the employers' association revealed that it wanted a more flexible organisation of working time and was willing to concede wage increases in return. These became the focal points of the negotiation. Although at the beginning of the process the parties were both reluctant and the employers' association presented a very rigid position, after three meetings they decided to move on to direct negotiations. When they came back for another conciliation meeting they were ready to close the procedure and sign the revised collective agreement.

In this case, the role of the conciliator was crucial in pointing out the importance of having a collective convention rather than the mere application of the Labor Code, which would be unquestionably further apart from the sector's reality. Eventually, the parties recognized the added value of reaching an agreement and found out the way to agree on the controversial terms.

\footnotetext{
A. Pinheiro · A. M. Passos $(\bowtie) \cdot$ A. Stoleroff

ISCTE_-Instituto Universitário de Lisboa, Lisbon, Portugal

e-mail: ana.passos@iscte-iul.pt 


\subsection{Introduction}

Over the last four decades, since the acquisition of basic democratic rights in labor relations, the Portuguese industrial relations system has evolved steadily (Barreto \& Naumann, 1998; Stoleroff, 2000). In fact, the success of its institutionalisation, after a revolutionary upheaval and in the context of the consolidation of a constitutional democratic political regime and gradual recuperation of civil society, can, to some degree, be deducted from the pattern and evolution of labor conflict and the role of third party intervention.

In the very early stages of Portuguese democratisation, following the revolutionary period of 1974-75, labor conflict was endemic to the emerging pattern of labor relations. However, since the deep economic crisis of 1983-85 and the organisational restructuring of the late 1980s and 1990s, the level of conflict has continuously decreased. Even with spikes of strike activity, most notably during the recent crisis years, the average level of open conflict has tended to fall. An explanation of this evolution would require looking at many factors and variables (Costa, Dias, \& Soeiro, 2014) and it is within this context that third party intervention should be examined.

During the period between 1986-2016 (represented on Fig. 11.1), strikes reflected an average number of lost working days per worker of less than 2 days, being 1 day the most common duration of a strike. In most recent years this number has been increasing, reaching a value of 1,8 days in 2016, equalling values from the early years of this century (source: Pordata).

Most recently, Portugal experienced another serious crisis, associated with the international financial crisis and the sovereign debt crisis of the Euro Zone, that had significant implications in all sectors of the economy. Between 2008 and 2014 GDP fell sharply and unemployment rose to record heights.

The country was forced to seek external assistance from the IMF, the European Commission and ECB in April 2011, submitting to an adjustment programme, defined in a "Memorandum of Understanding" with this Troika, that ended in June 2014. During the Economic and Financial Assistance Programme a set of "austerity

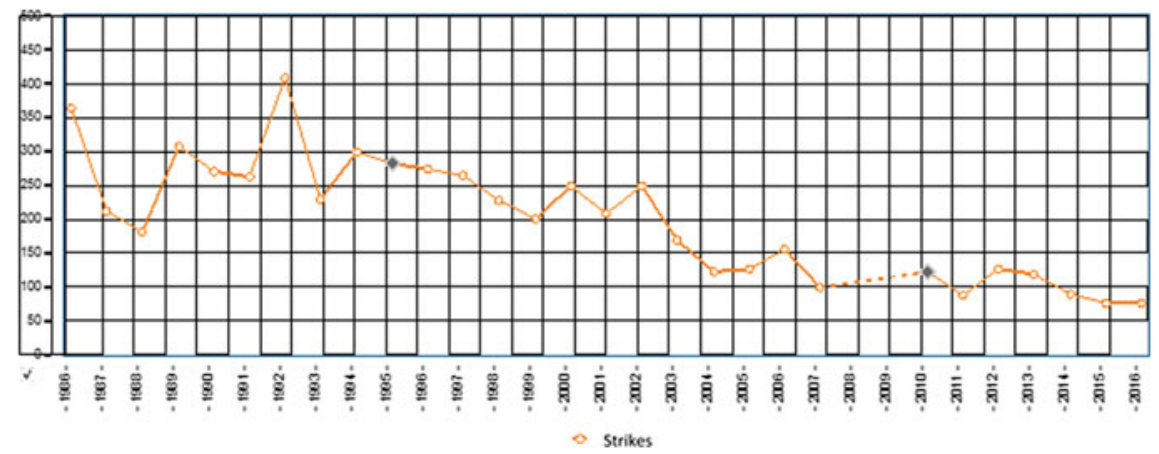

Fig. 11.1 Strike frequency-1986-2016 


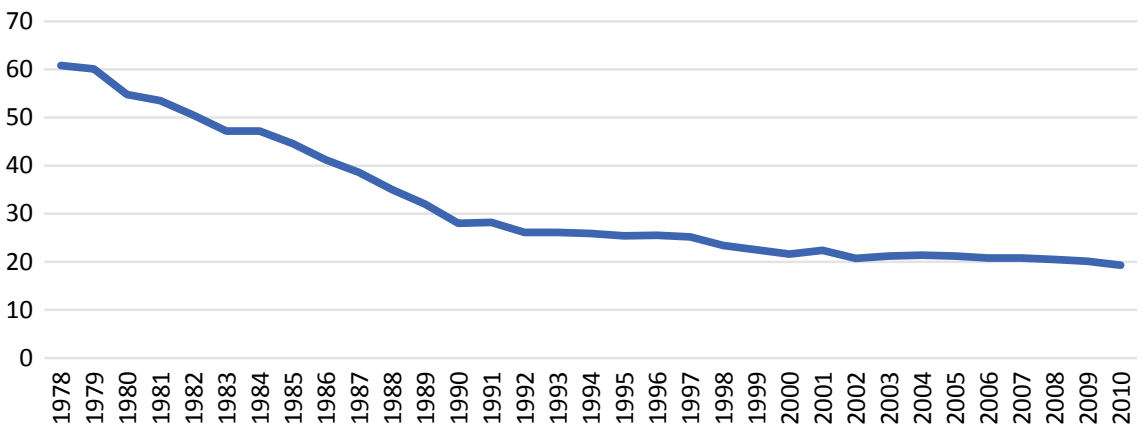

Fig. 11.2 Trade Union affiliation density. Source Costa, Dias, and Soeiro (2014)

measures" was implemented with the purported aim of reducing the deficit (from $11.2 \%$ at the end of 2010 to $4.4 \%$ at the end of 2015 and $3 \%$ in 2017; Source: Eurostat).

The budgetary constraints were felt most intensely in the public sector generally and in the public administration more specifically (Stoleroff, 2013). Amongst the measures applied to public employees were pay cuts, the suspension of the 13 th month vacation pay, a freeze on hiring and career progression and the receipt of Christmas allowances in twelfths. However, the MoU contained other measures aimed very broadly at reducing workers' rights and led to revisions of the Labor Code to facilitate dismissals, reduce compensation for dismissal and limit the coverage of collective bargaining.

The labor movement responded with strike actions, including various general strikes (Campos Lima, \& Martín Artiles, 2011; Costa et al., 2014). However, despite the increase in values registered during the crisis, especially between 2011 and 2014, it never came close to the values presented in the 80s and 90s. Most notably, strikes became endemic in the transport sector, which had a major impact on people trying to reach their daily workplace. The strikes with greater expression were probably those carried out by Metropolitano de Lisboa, but almost every transport company suffered strikes during the period of crisis.

Another aspect influencing the level of collective conflict is the significant and gradual reduction of union affiliation, as can be seen in Fig. 11.2. In conclusion, we can state that the number of strikes at company and workplace level, on the whole, continued its decline, while there has been a slight increase in sectoral disputes such as in transport and education sectors.

Currently, Portugal is undergoing a period of economic recovery, showing significant improvement in economic and financial indicators. As to be expected in a period of recovery, labor has been more assertive, particularly in the public sector, which has been marked by a series of strikes with significant participation, namely in Health and Education. It remains to be seen how recovery will affect the militancy and bargaining power of unions in private sector collective bargaining, which is where conciliation and mediation are most relevant since it is the source of most requests for intervention. 


\subsection{Characteristics of the System}

Work-related conflicts can be addressed by both the Ministry of Justice, when these are individual, and the Ministry of Labor, when conflicts are collective. In this chapter we are only focusing on the procedures associated with collective conflict resolution, which includes conciliation, mediation, arbitration and prevention processes. A large part of the information presented here is based on legislation, the Labor Code (Código do Trabalho), the website and documents produced by DGERT (Directorate-General for Employment and Labor Relations), an interview conducted with DGERT's Chief Executive, the interviews conducted with the mediators and various users of the system and the CES (Economic and Social Council) website.

In order to clarify the concepts, collective conflicts of rights are based on the interpretation or enforcement of an existing contract, while collective conflicts of interests refer to crisis situations in direct negotiation, where the parties are not able or not willing to continue negotiating until they reach a balanced solution between the interests they both represent (Fernandes, 2012).

In Portugal, the legal system tends to promote intervention in collective labor conflicts (Fernandes, 2012) and their management is regulated by basic recognized parameters, such as the freedom of trade union organization and action; the recognition and guarantee of the right to strike; the freedom to choose between negotiation procedures; the existence of imperative boundaries on the content and timing and sequence of formal negotiation procedures; and the provision of optional or voluntary methods for conflict resolution.

Collective conflicts stem from disagreements regarding the updating, revision or enforcement of an existing contract and its clauses or the negotiation of a new contract. In the case that a party to a collective conflict requests the intervention of a third party, the Labor Code stipulates three standard procedures: Conciliation ( $\mathrm{Art}^{\circ} \mathrm{s}$ 523-525), Mediation (Art ${ }^{\circ}$ s 526-528) and Arbitration ( Art $^{\circ}$ 529). There also exist procedures for the prevention of collective conflicts which involve the DGERT as third party. This latter function does not appear in the Labor Code, but rather derives from the DGERT's Organic Law, approved by the Regulatory Decree nr. 40/2012 of April 12th ( $\left.\mathrm{Art}^{\mathrm{o}} 2,4 \mathrm{c}\right)$.

The competent public entity involved in conciliation, mediation and prevention processes for the public and private sectors is the DGERT, which is a division within the Ministry of Labor, Solidarity and Social Security. It operates through two delegations for professional relations, one for the south (Directorate of Services for Professional Relations of Lisbon and Vale do Tejo, Alentejo and Algarve-DSRPLAA) and one for the north (Directorate of Services for Professional Relations in Northern and Central Regions-DSRPNC).

The services provided by DGERT are free of charge to the parties involved, facilitating the access to this collective conflict resolution service and helping to promote collective bargaining. 
The relevant responsibilities of the DGERT are in:

(a) Conciliation and mediation of collective labor disputes resulting from the conclusion or revision of collective agreements;

(b) Registry of information and participation in the negotiation process for Collective Dismissals ${ }^{1}$;

(c) Prevention of Collective Conflicts through assistance and intervention in labour relations in order to prevent or to surpass eventual collective conflicts;

(d) Definition of Minimum Services following the convocation of a strike by a union. $^{2}$

Arbitration, unlike the other three processes, involves issuing a binding decision/sentence by the arbitrator or arbitration committee. Decision takes place following examination of the opposing parties' claims and grounds for them, with or without hearing them directly. The key criterion of arbitration is equity, which means it is a question of defining the right solution to the conflict, within the lines set by the parties' final positions. As stipulated in the Labour Code, arbitration may take three distinct forms: mandatory arbitration, necessary arbitration and arbitration for the definition of minimum services.

The competent public body in the case of arbitration processes is the CES, the Economic and Social Council, which is the public organ for consultation and tripartite concertation in the economic and social field. In this context, the main roles of the CES are to organize and maintain the required lists for the purpose of appointing arbitrators (Presiding Arbitrators, Employer Arbitrators and Worker Arbitrators), to select the arbitrators when necessary, to guarantee the payment of arbitrators and experts and to provide the technical and administrative support to the functioning of the Arbitration Court.

There is a possibility for the conciliation and mediation procedures to be carried out by an entity other than the DGERT, that is, to be carried out by anyone to whom the parties assign this responsibility to, usually an external lawyer. In this case, the rules provided by the Labour Code become supplementary. The Ministry services must nevertheless be informed of the beginning and end of the process. In the specific case of mediation, there is also a possibility for parties to jointly request the minister responsible for labor to appoint a personality from the Presiding Arbitrators list (CES) to be a mediator in the conflict. If the minister agrees and the personality accepts the nomination as mediator, the costs are covered by the Ministry of Labour.

\footnotetext{
${ }^{1}$ The Labor Code requires employers to inform the DGERT, coincident with notification to the representative organizations of the employees, of an intention to dismiss. Collective dismissals involve situations where a company with less than 50 employees intends to dismiss 2 or more employees or where a company with 50 or more employees intends to dismiss 5 or more workers. Collective dismissals must be justified due to the closing of company units or economic, structuralorganizational or technological changes.

${ }^{2}$ The Labor Code requires registration of prior notice in the case of a union's call to strike and the negotiation of agreements regarding minimum services to be provided in case of a strike in a company or facility (public or private) that may affect the provision of essential social needs as well as the necessary means to ensure them.
} 
This study has focused on the conciliation, mediation and prevention procedures because the three involve negotiation between the parties. According to the Portuguese law, these are never compulsory, they always depend on the will and request of at least one party (see further explanation below).

\subsubsection{Evaluation of Stakeholders on the System}

Evidence from the interviews with the mediators showed that, in general, they are satisfied with the legal structure in which the system is established and believe that it is appropriate to the parties' needs and requests. They also believe that the system should be more widely disseminated to organizations, continuing the efforts to get closer to the business sector. A mediator said: "The social partners are increasingly aware of the importance of DGERT and they are seeking us (our services) more and more".

Regarding the parties, although they prefer to negotiate directly without the intervention of a third party, both the employers' and the workers' representatives appreciate the work and effort carried out by the DGERT, which they consider to be a reliable actor for the resolution of collective conflicts. The parties said to require DGERT's intervention, especially in two situations: (1) when direct negotiations reach an impasse, preventing them from moving forward on their own; (2) when companies are unwilling to receive trade unions to negotiate.

\subsection{Characteristics of the Mediators and the Third-Party Procedures}

In 2017 DGERT employed 11 mediators in total, divided between the two regional Directorates, 5 of them working in Lisbon and the other 6 in Porto. These professionals are called conciliators or mediators, according to the procedure they are carrying out (conciliation or mediation) and formally they are classified as senior technicians of the Public Administration, who work full-time in the Ministry and perform tasks exclusively related to the function of conciliator/mediator. Although the workload is not constant and there are differences over time, there is a common perception among all interviewed mediators that they perform a significant effort to fulfill their work and that the resources, mainly human resources are scarce given the number of processes.

All the members of the North's team are jurists, but in Lisbon's team only the Director has a background in law while the other mediators have a background in sociology. No specific training in negotiation or collective bargaining is required, and the mediators' initial training is on-the-job, attending meetings together with 
Table 11.1 Requested conciliations (2010-2016)

\begin{tabular}{l|l|l|l|l}
\hline \multirow{2}{*}{ Years } & \multicolumn{4}{l}{ Conciliation processes } \\
\cline { 2 - 5 } & Requests & $\begin{array}{l}\text { Concluded with } \\
\text { conciliation agreement }\end{array}$ & $\begin{array}{l}\text { Concluded without } \\
\text { conciliation agreement }\end{array}$ & Concluded-total \\
\hline 2010 & 85 & 35 & 38 & 73 \\
\hline 2011 & 77 & 29 & 51 & 80 \\
\hline 2012 & 35 & 15 & 20 & 35 \\
\hline 2013 & 52 & 19 & 33 & 52 \\
\hline 2014 & 61 & 33 & 25 & 61 \\
\hline 2015 & 63 & 20 & 22 & 42 \\
\hline 2016 & 38 & 17 & 21 & $38^{*}$ \\
\hline
\end{tabular}

Source DGERT $* 28$ conciliation processes open and on going

more experienced conciliators. The conciliator is expected to take charge of his/her own processes only a few months afterwards.

During the year, there are occasional training sessions and seminars, mostly related to Labor Law and Legislation, not specifically addressing issues such as negotiation or collective conflict resolution procedures. Apart from those annual training activities, all of the staff with more than 1 year of experience had been given the opportunity to attend a Certification Course on Conciliation/Mediation of Labour Disputes in the International Training Centre of the ILO. The members from Lisbon have also been given the opportunity to attend a graduate program in Labor Law and Social Security.

In Portugal, on an annual basis, approximately 40 conciliations, 10 mediations and 90 prevention procedures take place, facilitated by the official mediators from DGERT (see Tables 11.1, 11.2 and 11.3). The processes can go from one year to the next if they are not concluded within the same year of the request and that is why it is possible to conclude more processes than those requested. It is not useful to calculate the number of meetings that took place within these processes nor the average, due to the great variation in processes. We were informed of a conciliation process that lasted only 3 meetings and another that took at least 15 meetings before the final agreement was achieved.

\subsubsection{Evaluation by Stakeholders of the Mediators and Third-Party Procedures}

All the mediators that we interviewed considered the Certification Course from the ILO to have been a very valuable and useful tool for the performance of their functions. They pointed out that the most important aspects were to set a common 
Table 11.2 Requested mediations (2010-2016)

\begin{tabular}{l|l|l|l|c}
\hline \multirow{2}{*}{ Years } & \multicolumn{4}{l}{ Mediation processes } \\
\cline { 2 - 5 } & Requests & $\begin{array}{l}\text { Concluded with } \\
\text { mediation agreement }\end{array}$ & $\begin{array}{l}\text { Concluded without } \\
\text { mediation agreement }\end{array}$ & Concluded-total \\
\hline 2010 & 14 & 1 & 1 & 2 \\
\hline 2011 & 15 & 0 & 10 & 10 \\
\hline 2012 & 8 & 1 & 7 & 8 \\
\hline 2013 & 7 & 1 & 6 & 11 \\
\hline 2014 & 11 & 1 & 10 & 7 \\
\hline 2015 & 11 & 2 & 5 & $10 *$ \\
\hline 2016 & 10 & 1 & 9 & \\
\hline
\end{tabular}

Source DGERT $* 5$ mediation processes open and on going

Table 11.3 Prevention processes (2010-2016)

\begin{tabular}{l|l|l|l|l}
\hline \multirow{2}{*}{ Years } & \multicolumn{4}{l}{ Prevention processes } \\
\cline { 2 - 5 } & Requests & $\begin{array}{l}\text { Concluded with } \\
\text { agreement }\end{array}$ & $\begin{array}{l}\text { Concluded without } \\
\text { agreement }\end{array}$ & Concluded-total \\
\hline 2010 & 63 & 39 & 18 & 57 \\
\hline 2011 & 77 & 44 & 18 & 62 \\
\hline 2012 & 78 & 57 & 21 & 78 \\
\hline 2013 & 85 & 56 & 29 & 85 \\
\hline 2014 & 65 & 49 & 16 & 65 \\
\hline 2015 & 80 & 49 & 24 & 73 \\
\hline 2016 & 90 & 59 & 29 & $88 *$ \\
\hline
\end{tabular}

Source DGERT $* 15$ prevention processes open and on going

basis for the way of working as a conciliator and to learn best practices from different countries and realities.

An aspect mentioned by most of the interviewees is related to the definition of the Statute of the Mediator. This raises some issues, namely, problems of confidentiality in the mediator's action. The mediators expressed concerns regarding the lack of confidentiality rules for proceedings, meetings and minutes, meaning that the parties may disclose what is said in negotiation meetings, which is often not beneficial to the negotiation process and can in certain situations even exacerbate the conflict. ${ }^{3}$

Evidence from the interviews with both employers' and employees' representatives show that there is a general feeling of trust towards the mediators' work.

\footnotetext{
${ }^{3}$ In the words of one mediator: "If the parties don't feel at ease to speak freely, the negotiation will not be as fruitful as it could be."
} 
The parties believe in the neutrality of the conciliators/mediators and trust them to facilitate dialogue throughout the conflict in negotiations. ${ }^{4}$

\subsection{Description of the Conciliation, Mediation and Prevention Processes}

Conciliation and mediation are both intended to promote agreement on the conclusion or revision of a collective agreement, but there are some differences in the processes and procedures.

Conciliation, usually the first stage of the process, is "assisted negotiation" where a third party is involved in order to help the parties find agreement. This may be a representative of the state (from DGERT) or a figure chosen by the parties involved. This procedure may be initiated either by agreement of the parties or on the initiative of only one of them, in the absence of a response to a proposal to conclude/revise a collective agreement or following 8 days' written notice to the other party. The extent and form of this intervention are highly variable; it may involve only procedural support or go beyond to the formulation of proposals/suggestions to the parties.

Prevention of collective conflicts is a similar process to conciliation-an assisted conversation without proposals by the mediators. The difference is that conciliation arises from a collective bargaining process, while prevention arises from other conflicts between parties, for example an interpretation of the collective agreement-right conflict—or other conflict of interest between unions and company (https://www.dgert.gov.pt).

Mediation is where the third party—a mediator appointed by DGERT—draws up a recommendation or proposed solution after having researched the positions of the parties and the grounds for their positions. As in conciliation, the request may be based upon the application of both parties or only one, provided that a conciliation process has already taken place with the duration of at least one month. The main goal is to promote an agreement between the actors and the ultimate result of successful mediation would be the signing of a collective convention, in whole or part. The fundamental criterion of mediation is efficacy when looking for the best agreement possible, and the role of the mediator is not to point to the fairest solution, but rather to discover and present to the parties a proposal that represents the closest approximation between their opposing positions.

Concerning the procedure to arrange a third party, regardless of the process, every request starts with an e-mail sent by one or both parties, usually the trade union, to the DGERT's office. It must indicate the purpose for the intervention and its object. Then, the DGERT verifies the validity of the request, assigns a conciliator/mediator and convenes the parties to start the negotiation process within 10 days of the request. It

\footnotetext{
${ }^{4}$ One employer representative said, "I absolutely believe that the parties trust the mediators' intervention. We have very competent and dedicated professionals and I have the best perception about them."
} 
not possible for the parties to refuse to participate in conciliation/mediation processes without prior notice and valid justification and there are fines for unjustified absences of the parties.

In conciliation, the meeting participants are the parties-employer and union - and the conciliator appointed by DGERT. When conciliation concerns the revision of a collective agreement, the DGERT's services should invite union or employers' associations involved in that agreement even if they have not requested conciliation. Conciliation may conclude in agreement or non-agreement on the negotiated subjects. The result of the process, even when there is an agreement, is a protocol signed by the parties and the conciliator, but it is not subject to registration or publication. This document may be substantiated by a collective agreement, if and to the extent that the parties so decide.

Regarding mediation, the participants are the parties - employer and union-and the mediator appointed by DGERT. Mediation begins with the definition of the object. The legal framework, which is supplementary, defines the following stages:

- If mediation has been required by only one of the parties, the mediator must request the other side to decide on the object and, if there is a disagreement, it is the mediator who decides regarding feasibility of the mediation;

- The mediator must send the proposal to the parties within 30 days of its appointment, after meeting separately with both parties (more than one meeting may occur);

- The parties have 10 days from the receipt of the proposal to notify the mediator of their acceptance;

- After receiving the replies or after 10 days, the mediator must notify the parties of the acceptance or rejection of the proposal within 2 days.

The parties may accept the mediator's proposal in whole or partially or reject it. The proposal, even if accepted by both parties, is not subject to registration or publication. It is up to the parties to transform the agreement into the formal text of the collective agreement for subsequent registration.

All the cases are distributed internally and the parties have no choice regarding the responsible mediator. For example, in Lisbon the mediators are organized by industrial branches, which means that a certain branch is generally going to be dealt with by the same mediator. In Porto, however, this is not the method and cases are distributed by the Director with the aim of rotating branches amongst the mediators.

\subsubsection{Evaluation by Stakeholders of the Mediators and Mediation Processes}

The requests for conciliation are mostly made, unilaterally, by trade unions. As a mediator stated, "Almost all of our work is due to union initiative; it is very rare for a company to ask for conciliation, mediation or prevention. Usually, dissatisfaction 
comes from unions. Lately, we have started to have some requests from companies". This might happen because companies are currently getting to know better DGERT's service.

It is unanimous among all the interviewees that the most recurrent issues in collective conflicts, and those that raise the most disagreements, are wage scales, cash benefits and the organization of working time (supplementary work, flexible overtime accounts and adaptability).

As stated earlier, the extent and form of conciliation are very variable because they truly depend on the parties' will, as we can understand by this mediator's statement: "There are cases that go beyond this (facilitation of dialogue) to try to unlock the negotiation, but everything depends on the willingness, openness and the mandate with which the parties come to the meetings". Furthermore, the conciliators have the freedom to choose from separate or joint meetings, selecting what they think fits best the type of conflict and relationship between the parties.

In general, the action in the different procedures varies from mediator to mediator, because as one mediator says: "We all have the same basis, identical, but then each of us adopts his own style of action, which depends on the way of being and expressing of each mediator". The basis for mediators' work is given by what is described on the Labor Code, but in practice the decisions such as the number of meetings, being with both parties or only one, be more or less interventive, are the sole responsibility of the mediator. Within the procedure that is stipulated by law the mediator can try different approaches in order to reach a more favorable result and they usually find it helpful to adapt the approach according to the interlocutor they are dealing with and its negotiation style.

\subsection{Effectiveness of the System}

Firstly, conciliation is by far more frequently requested by the actors than mediation. The number of mediation processes is consistently significantly lower than conciliations. In 2015 there were 11 mediation requests against 63 for conciliation (see Table 11.2). On the other hand, it is difficult to establish a regular pattern in requests for conciliation and mediation. Between 2010 and 2016, the number of requests tended to decrease, both for mediation and conciliation. Regarding prevention processes the requests have been increasing, surpassing the number of conciliation requests since 2011 and representing a large part of mediators' workload, with 90 requested interventions in 2016.

One way of measuring the effectiveness of the system of third party intervention is obviously based upon its ability to produce agreements. Focusing only on the processes of conciliation and mediation carried out by DGERT, it is notable that the majority of processes do not produce agreements. Nevertheless, it be can observed that conciliation processes and prevention process tend to produce significantly more agreements than do mediations. With the exception of the outlying year of 2010, the percentage of conciliation processes producing agreement was much greater than for 
Fig. 11.3 Concluded conciliations (2010-2016)

Fig. 11.4 Concluded mediations (2010-2016)
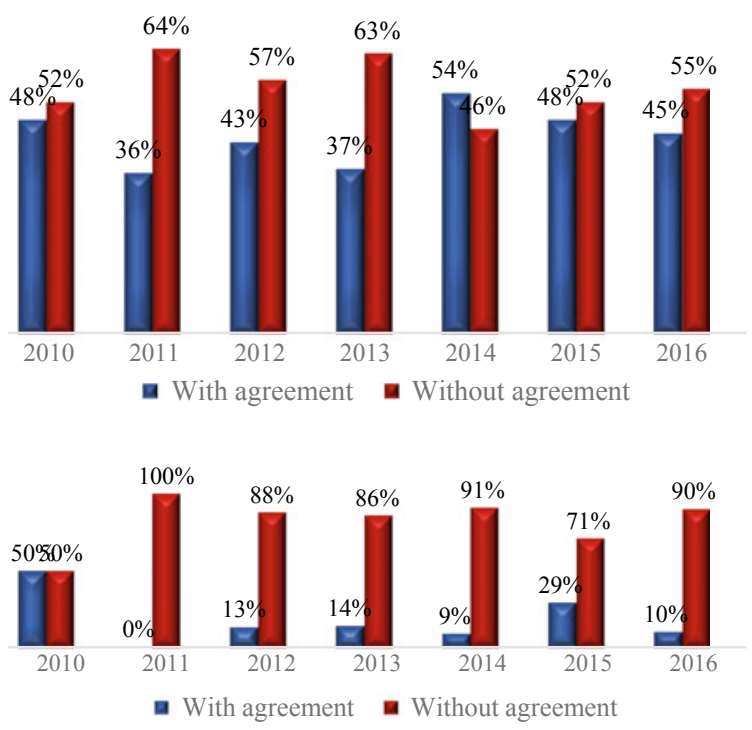

Fig. 11.5 Concluded preventions (2010-2016). Source DGERT

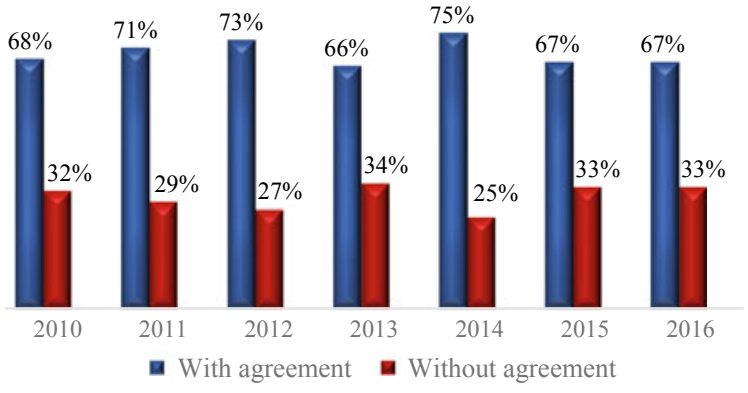

mediations, and prevention processes have higher agreement rates than conciliations. In 2016, for example, $67 \%$ of the prevention processes and $45 \%$ of the conciliations resulted in an agreement, against only $10 \%$ in mediation processes (see Figs. 11.3, 11.4 and 11.5). These data suggest that conciliation is more effective as a mechanism to manage escalated conflicts, rather than a conciliation used in a process of collective bargaining, requested for one of the parties.

However, as we understand from the information gathered in the interviews with DGERT's Chief Executive and mediators, this reduced rate of success in mediation may have to do with the fact that most mediation requests are related to a wage and salary issues, which is very challenging since the employers tend to demand concessions in exchange for adjustments that workers' representatives are not willing to accept, mostly regarding the organisation of working hours. 


\subsubsection{Evaluation by Stakeholders of the Effectiveness of the Mediation}

In fact, there is no evaluation of the third-party intervention system in Portugal that goes beyond the registration of agreements and non-agreements of conciliation, mediation and prevention processes. That being said, evaluating effectiveness depends largely on the opinions gathered in the interviews as we believe in this case the statistics are a very limitative way to measure the effectiveness of the work carried out through these procedures.

Interviewed mediators told that although sometimes reaching an agreement is impossible, almost always they perceive an improvement in relationships between the parties that help them negotiate in future encounters. There is a shared idea that negotiating is never a loss because it opens the doors for conversation and exchange of ideas that can ultimately help the parties understand each other's grounds and compromise to a solution.

From the collected data we can see that feedback is needed in DGERT and would be very much appreciated by the mediators, even to improve their satisfaction at work when the results are not so visible. As one mediator stated: "We try to individually come up with different strategies. We don't share experiences with other colleagues, we just tell the Service Director about the cases, but we never receive feedback". Only with constructive feedback and shared experiences will it be possible to learn from each other and gather best practices from each mediator, in order to seek the higher rate of agreements.

\subsection{Conclusion}

Over the last two years, Portugal's economy seems to be recovering from the crisis. With the significant change in the government's orientation, significant efforts are being made, simultaneously involving concertation and struggle, to regenerate its industrial relations system and restore working conditions and standards in the context of the post-austerity era. While we have to acknowledge the importance of social dialogue in this process, industrial relations remain under significant constraints and there is significant tension amongst actors at all levels of the system, including its articulations with political actors and the political system.

However, it is predictable that conflict will increase with economic recovery and growth as employers require labour and the labour market becomes less elastic. Workers tend to sense opportunity for betterment of their negotiating positions and employers are still in need to recover their margins and make new investment. The context is thus ripe for conflict and the role of third party intervention may, as a result, become an ever more important resource for the resiliency of the industrial relations system. 


\section{References}

Barreto, J., \& Naumann, R. (1998). Portugal: Industrial relations under democracy. In A. Ferner \& R. Hyman (Eds.), Changing industrial relations in Europe (pp. 395-425). Oxford: Blackwell.

Campos Lima, M., \& Martín Artiles, A. (2011). Crisis and trade union challenges in Portugal and Spain: Between general strikes and social pacts. European Review of Labor and Research, 17(3), $387-402$.

Costa, H. A., Dias, H., \& Soeiro, J. (2014). As greves e a austeridade em Portugal: Olhares, expressões e recomposições. Revista Crítica de Ciências Sociais, 103(May), 173-202.

DGERT. (2017). Relações Profissionais - Relatório anual (2010-2016) [PDF]. Retrieved from www.dgert.gov.pt/relatorio-anual-das-relacoes-profissionais.

Fernandes, A. M. (2012). Direito do Trabalho. Lisbon: Almedina.

Stoleroff, A. (2000). Portugal: Union development within the changing contexts of political economy and industrial relations. In J. Waddington \& R. Haffman (Eds.), Trade unions in Europe: Facing challenges and searching for solutions (pp. 451-497). Brussels: ETUI.

Stoleroff, A. (2013). Employment relations and unions in public administration in Portugal and Spain: From reform to austerity. European Journal of Industrial Relations, 19(4), 309-323.

Open Access This chapter is licensed under the terms of the Creative Commons Attribution 4.0 International License (http://creativecommons.org/licenses/by/4.0/), which permits use, sharing, adaptation, distribution and reproduction in any medium or format, as long as you give appropriate credit to the original author(s) and the source, provide a link to the Creative Commons license and indicate if changes were made.

The images or other third party material in this chapter are included in the chapter's Creative Commons license, unless indicated otherwise in a credit line to the material. If material is not included in the chapter's Creative Commons license and your intended use is not permitted by statutory regulation or exceeds the permitted use, you will need to obtain permission directly from the copyright holder. 